\title{
Towards the trophic structure of the Bouvet Island marine ecosystem
}

\author{
Received: 6 June 2005/ Revised: 7 September 2005/ Accepted: 14 September 2005/Published online: 19 October 2005
} (C) Springer-Verlag 2005

\begin{abstract}
Although Bouvet Island is of considerable importance for Southern Ocean species conservation, information on the marine community species inventory and trophic functioning is scarce. Our combined study of stable isotopes and feeding relationships shows that (1) the marine system conforms to the trophic pattern described for other Antarctic systems within the Antarctic circumpolar current (ACC); (2) both the benthic and the pelagic subsystem are almost exclusively linked via suspended particulate organic matter (SPOM); and (3) there is no evidence of a subsystem driven by macroalgae. Bouvet Island can therefore be characterized as a benthic "oasis" within a self-sustaining open ocean pelagic system.
\end{abstract}

U. Jacob $(\bowtie) \cdot$ T. Brey $\cdot$ K. Mintenbeck $\cdot$ K. Beyer · W.E. Arntz Alfred Wegener Institute for Polar and Marine Research, PO Box 120161, 27515 Bremerhaven, Germany

E-mail: ujacob@awi-bremerhaven.de

S. Kaehler

Southern Ocean Group, Rhodes University,

PO Box 94, Grahamstown 6140, South Africa

K. Dunton

Marine Science Institute, University of Texas,

750 Channelview Drive Port, Austin, TX 78373-5015, USA

U. Struck

GeoBio-Center at Ludwig-Maximilans-Universität,

Richard-Wagner-Strasse 10, 80333 München, Germany

I. Fetzer

Centre for Environmental Research Leipzig-Halle,

Permoserstraße 15, 04318 Leipzig, Germany

E.A. Pakhomov

Zoology Department, Faculty of Science and Technology,

University of Fort Hare, Private Bag X1314,

Alice 5700, South Africa

E.A. Pakhomov

Department of Earth and Ocean Sciences, University of British Columbia, Stores Road, Stores Road, Vancouver, BC, V6T 1Z4, Canada

\section{Introduction}

Bouvet Island (Bouvetøya, 54 $72^{\prime} 60 \mathrm{~S}, 3^{\circ} 24^{\prime} \mathrm{E}$ ) is located just south of the Antarctic Polar Front (APF) and within the Antarctic circumpolar current (ACC, Fig. 1, Foldvik et al. 1981; Perissinotto et al. 1992). Owing to its geographical isolation (i.e. $2,590 \mathrm{~km}$ downstream of the South Sandwich Islands, $2,570 \mathrm{~km}$ upstream of the Prince Edward Islands and 1,600 km north of Queen Maud Land, Antarctica) the island represents a pristine environment and has been identified as an important case study for the conservation of intact ecosystems (Chown and Gaston 2002). Nevertheless, marked climate change and subsequent invasion of hitherto alien species have already affected other remote systems of the Southern Ocean (e.g. South Georgia; Bergstrom and Chown 1999; Chown and Gaston 2002; Gaston et al. 2003; Frenot et al. 2005) and may thus endanger the ecology of Bouvet Island, too. Unfortunately, to date, next to nothing is known about the Bouvet Island marine community species inventory and the trophic functioning of the system. From existing oceanographic, biogeographic and ecological data we can infer that (1) the pelagic compartment of the Bouvet ecosystem is part of the Antarctic surface water ecosystem (ASW; Perissinotto et al. 1992), i.e. we expect ASW species inventory and trophic structure; (2) the Bouvet inventory of top predatory birds and mammals, albeit enormous in numbers and biomass (Cooper et al. 1984; Croxall 1984; Haftorn 1986; Isaksen et al. 2000; Kirkman et al. 2001; Keith et al. 2002) resembles that of other Sub-Antarctic islands such as the Prince Edward Islands (Perissinotto et al. 1990; Perissinotto and McQuaid 1992; Pakhomov and Froneman 1999); and (3) the benthic compartment of the Bouvet ecosystem should be structured accordingly, with a typical macroalgal depth zonation and a fauna characteristic for systems shaped by strong currents, though species composition may differ from comparable sites such as the South Sandwich Islands (LAMPOS; Jacob et al. 
2003; Arntz and Brey 2003) or the Prince Edwards Islands (Kaehler et al. 2000).

Here we present the first attempt towards a better understanding of the Bouvet Island food web based on stable isotope signatures of nitrogen and carbon and information on the diet of the most significant species.

\section{Material and methods}

Sampling of marine flora and fauna was conducted near Bouvet Island during RV "Polarstern" cruise ANT XXI/2 in 2003/2004 (Fig. 1, Arntz and Brey 2005). Four Agassiz trawl samples (mouth opening $3 \mathrm{~m} \times 1 \mathrm{~m}$, $10 \mathrm{~mm} \times 10 \mathrm{~mm}$ cod end mesh size, $20 \mathrm{~min}$ trawl time) were taken between 100 and $550 \mathrm{~m}$ water depth. Abundant taxa were identified to species level whenever possible, and sampled for stable isotope analysis. Small organisms were sampled whole, whereas pieces of body wall or muscle tissue were sampled from macro and megafaunal specimens. A total of four macroalgal samples (Rhodophyta spp.), 96 invertebrate samples of benthic and hyperbenthic invertebrates referring to 15 different taxa (among them decapods, amphipods, bryozoans, crinoids, holothurians, nemerteans, cnidarians, polychaetes, pycnogonids and asteroids) and ten samples of the nototheniod fish Lepidonotothen larseni were collected (Table 1). All samples were kept frozen at $-30^{\circ} \mathrm{C}$ until further analysis.

\section{Stable isotope signatures}

$\delta^{13} \mathrm{C}$ and $\delta^{15} \mathrm{~N}$ signatures serve as proxies of the trophic distance of an organism from the primary food source of the corresponding food chain. $\delta^{13} \mathrm{C}$ signatures are commonly used as valuable carbon source tracers (e.g. Lesage et al. 2001), whereas $\delta^{15} \mathrm{~N}$ values are a useful tool for detecting the trophic position and therefore the trophic hierarchy of the system. Samples were lyophilisated for $24 \mathrm{~h}$ in a Finn-Aqua Lyovac GT2E and then ground to a fine powder. Each sample was acidified to remove $\mathrm{CaCO}_{3}$ in accordance with Fry (1988), Cloern et al. (2002) and Jacob et al. (2005) by adding $1 \mathrm{~mol} \mathrm{l}^{-1}$ hydrochloric acid $(\mathrm{HCl})$ drop-by-drop until $\mathrm{CO}_{2}$ release stopped, re-dried at $60^{\circ} \mathrm{C}$ without rinsing to minimize loss of dissolved organic matter and ground again. Stable isotope analysis and concentration measurements of nitrogen and carbon were performed simultaneously with a THERMO/Finnigan MAT Delta plus isotope ratio mass spectrometer, coupled to a THERMO NA 2500 elemental analyzer via a THERMO/Finnigan Conflo II- interface. Stable isotope ratios are given in the conventional delta notation $\left(\delta^{13} \mathrm{C} ; \delta^{15} \mathrm{~N}\right)$ relative to atmospheric nitrogen (Mariotti et al. 1984) and PDB (PeeDee Belemnite standard). Standard deviation for repeated measurements of lab standard material (peptone) proved to be better than $0.15 \%$ for nitrogen and carbon. Standard deviations of concentration measurements of replicates of our lab standard are $<3 \%$ of the concentration analyzed.

In order to fill gaps in invertebrate and macroalgae species coverage, we added some stable isotope data referring to other sub-Antarctic localities, i.e. Prince Edward Island (Kaehler et al. 2000, 2005) and Anvers Island (Dunton 2001) (Fig. 1). Isotope signatures of Antarctic seabirds, mammals and particulate organic matter (POM) were taken from Rau et al. (1991, 1992), E.A. Pakhomov (unpublished data) and K. Mintenbeck (unpublished data). Data for the pelagic predatory squid Kondakovia longimana were taken from Wada et al. (1987).
Fig. 1 Map showing Anvers Island, South Sandwich Islands, Bouvet Island and the Prince Edward Islands. Grey band indicates region of the Antarctic circumpolar current (ACC)

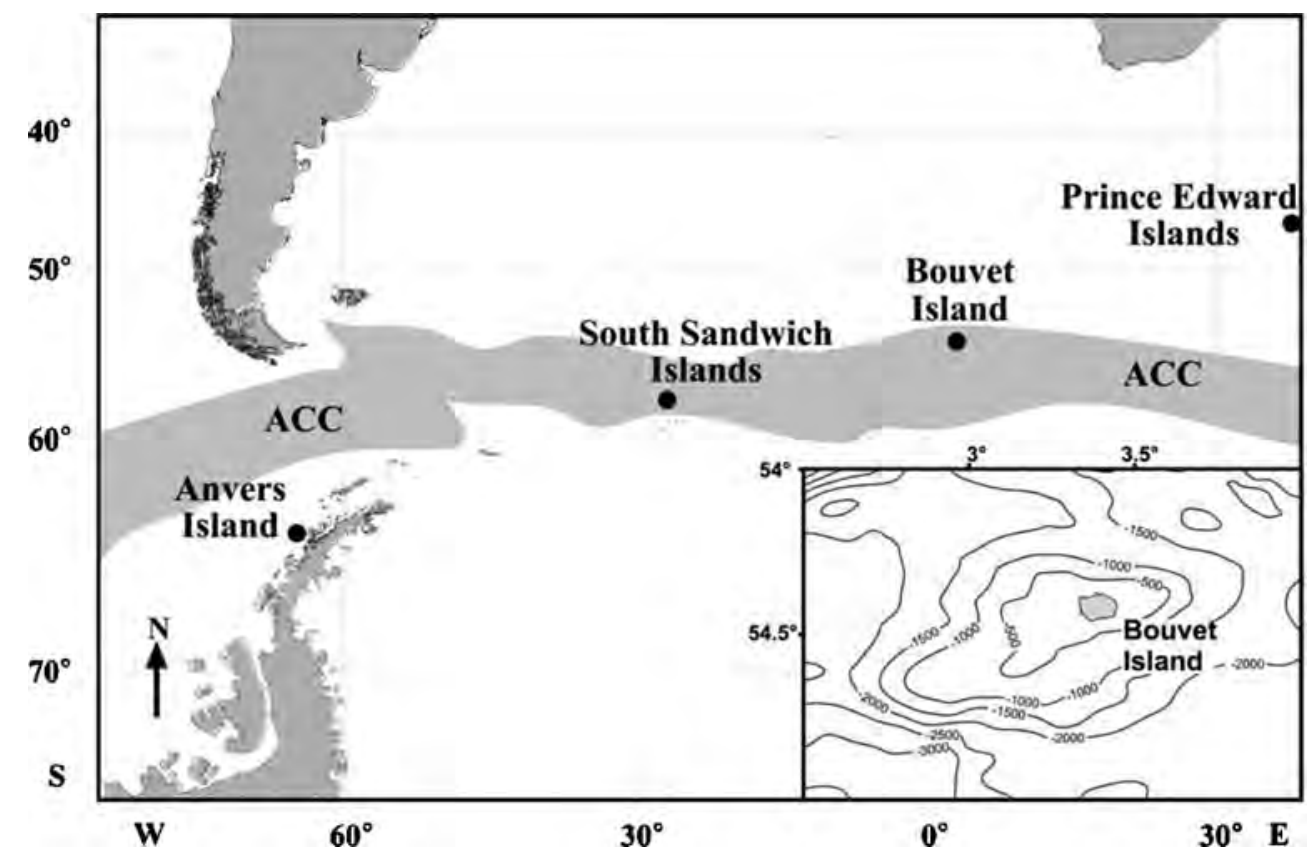


Table 1 Summary of taxa sampled, isotope signatures and the source of the data used to compile the trophic structure of the marine ecosystem of Bouvet Island

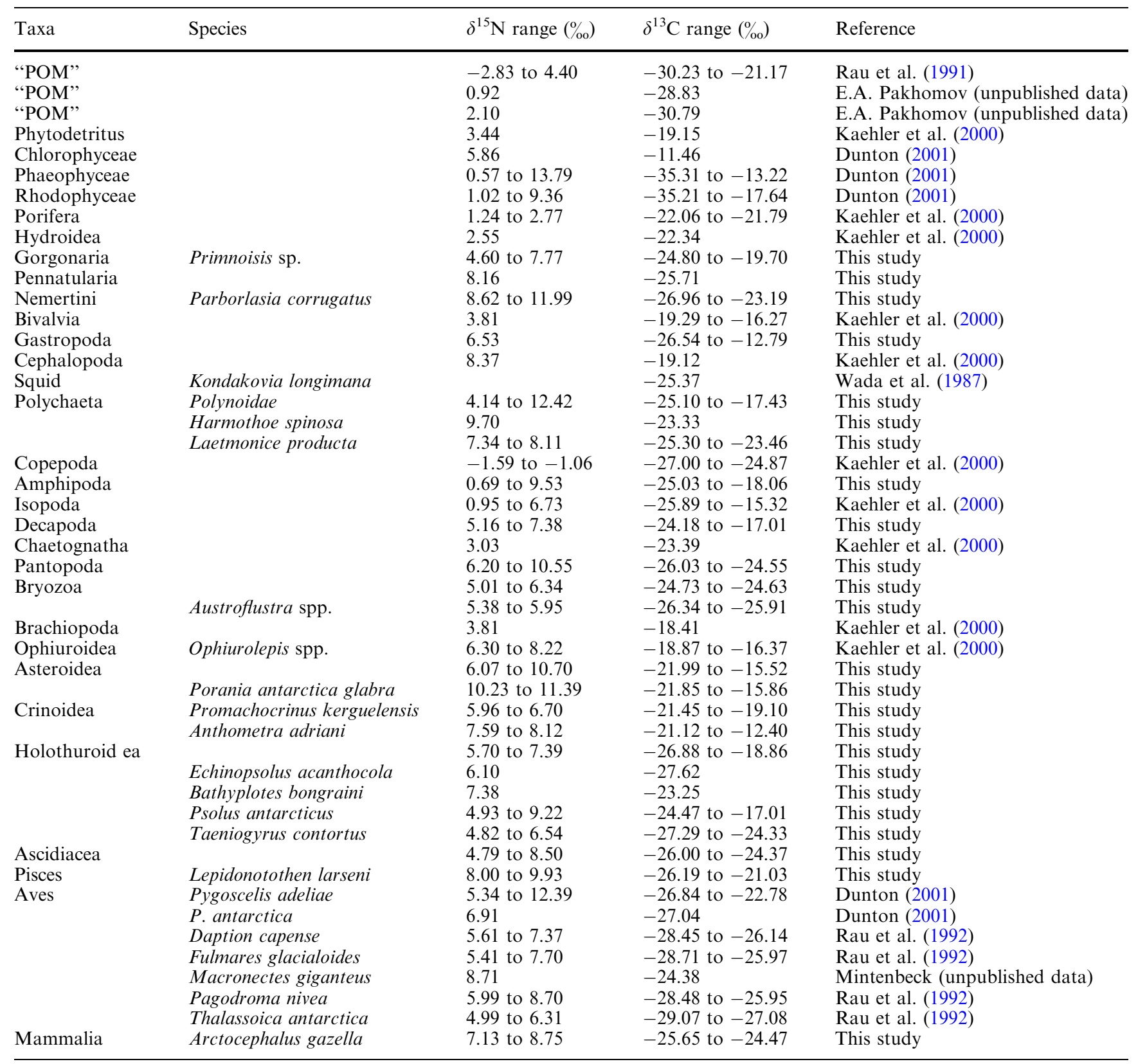

Feeding relationships

Information on feeding links between species occurring in the Bouvet Island ecosystem was collected by a thorough literature search. Following the approach of Martinez (1991), a directional feeding link was assigned to any pair of species A and B whenever an investigator reports or assumes that A consumes B. Suspended particulate organic matter (SPOM) is considered as a nonpredatory taxon as it includes significant resources (dead organic matter, nano- and micro-plankton) for many benthic invertebrates and is therefore itself a highly interacting system (Warren 1989; Walker 1985; Hall and Raffaelli 1991).

\section{Results}

Judging from the trawl sample debris, the seafloor around Bouvet Island was covered by coarse sands, stones and gravel (see also Arntz and Thatje 2005). Accordingly, the benthic system was dominated by typical hard bottom life forms. Crinoids (e.g. Anthometra adriani), holothurians (e.g. Taeniogyrus contortus) and asteroids (e.g. Porania antarctica glabra) were dominant in the Agassiz trawl samples. Red macroalgae and hydroids were also common, as well as bryozoans (mainly Austroflustra spp.) and some large sponges and gorgonians (mainly Primnoisis sp.). Other dominant 
Fig. $2 \delta^{15} \mathrm{~N}$ and $\delta^{13} \mathrm{C}$ signatures of the marine flora and fauna of Bouvet Island. Signatures for missing compartments (e.g. zooplankton, and land-based predators) are added from other localities as described in the text, a (filled circle) Anvers Island, (filled diamond) Bouvet Island, (filled triangle) Prince Edward Islands, (filled square) Weddell Sea b (filled diamond) benthic primary producers, (filled triangle) pelagic primary producers; c (filled triangle) benthic predators, (inverted triangle) benthic suspension feeders, (filled diamond) benthic deposit feeders; d (filled diamond) land-based (filled triangle) predators, pelagic predators, (inverted triangle) zooplankton; (open circle) all signatures used in the study (Table 1)
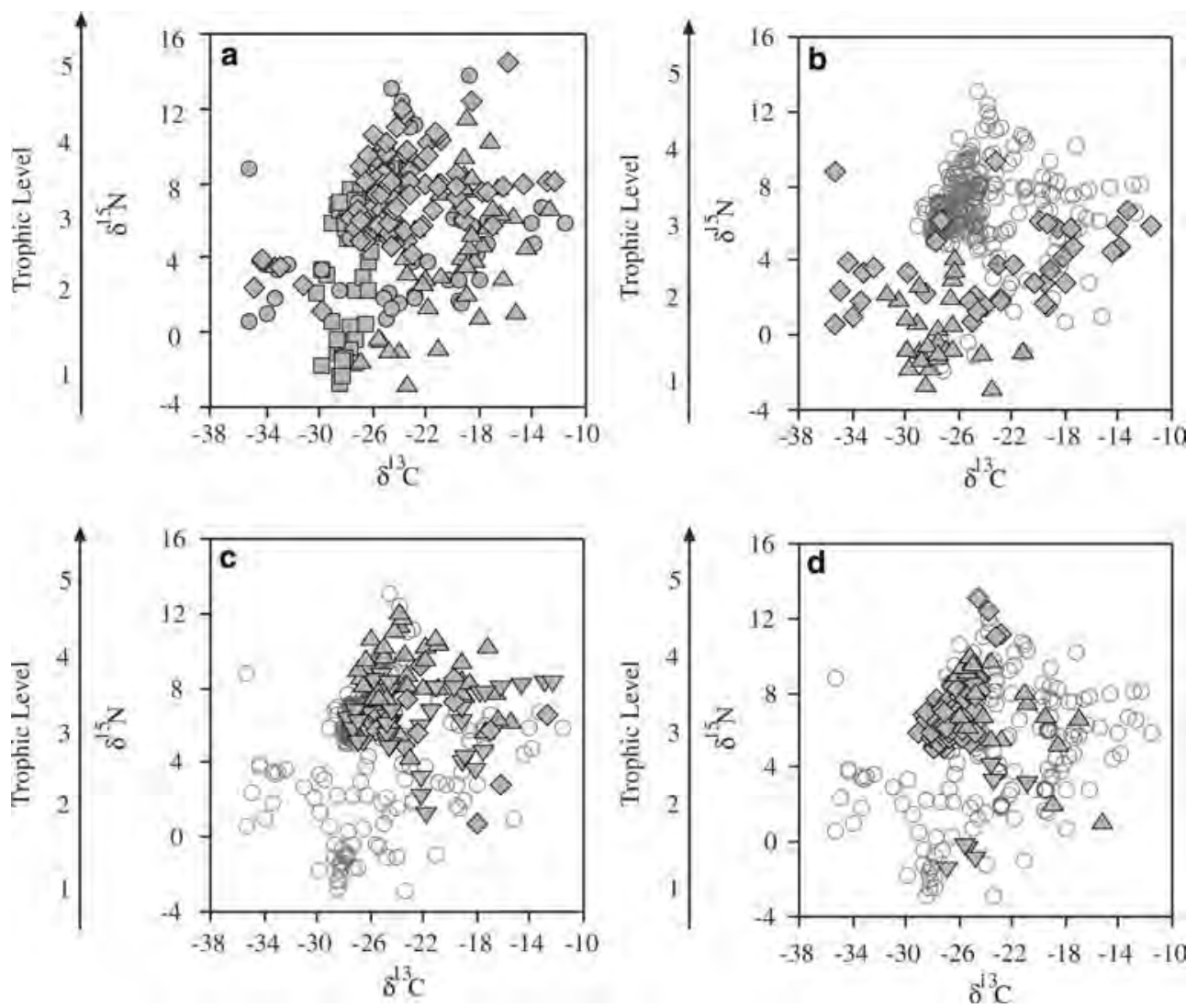

elements were serpulid polychaetes, small amphipods (Caprellidae and Lyssianassidae), small pycnogonids and the nototheniid fish species $L$. larseni and L. kempi. Typical infaunal or epifaunal deposit feeders like echinoids, sipunculids and echiurids were absent (Arntz and Thatje 2005).

\section{Stable isotope signatures}

Among the food sources of the marine ecosystem of Bouvet Island, POM signatures ranged from -28.83 to -30.79 in $\delta^{13} \mathrm{C}$ and from -0.92 to 2.10 for $\delta^{15} \mathrm{~N}$ (E.A. Pakhomov, unpublished data). Isotopic composition of macroalgae ranged from -11.5 to less than $-35 \%$ in $\delta^{13} \mathrm{C}$ and from 0.6 to $9.4 \%$ in $\delta^{15} \mathrm{~N}$ (Fig. 2b; Table 1).

With regard to $\delta^{15} \mathrm{~N}$ of the fauna, copepods had the lowest values. $\delta^{15} \mathrm{~N}$ values ranged between -1.06 and $-1.59, \delta^{13} \mathrm{C}$ values between -24.87 and -27.0 (Table 1 ). The Adelie penguin (Pygoscelis adeliae) and benthic predators like the nemerteans had the highest values (Table 1).

\section{Feeding relationships}

Two hundred and eighty-two feeding links connecting 58 different taxa were inferred from the literature. The preliminary food web shown in Fig. 3 indicates a distinct separation between (1) a bentho-demersal compartment highly entangled within itself and coupled to the SPOM box and (2) a pelagic compartment, coupled to the SPOM box and zooplankton.

\section{Discussion}

Scattered and missing data are one of the primary concerns when analyzing structural properties such as food webs of remote and poorly investigated systems (Connor and Simberloff 1978; Gaston 1996). On the other hand, stable isotope signatures are vulnerable to misinterpretation owing to their relative ease of use and assumed simplicity in interpretation (Gannes et al 1997; Schmidt et al. 2003). In order to compensate for these shortcomings we (1) combined information on general trophic hierarchy (stable isotope signatures $\delta^{13} \mathrm{C}$ and $\delta^{15} \mathrm{~N}$ ) with information on trophic links (diet composition) as recommended by Vander Zanden et al. (2000) and (2) added data from other, ecologically comparable SubAntarctic locations.

Regarding the pelagic community as well as long ranging top predators (seabirds, mammals, pelagic cephalopods), there is no evidence that trophic position derived from stable isotope signatures or feeding relations differ distinctly between sites within the ACC (Fig. 1), as is to be expected in a uniform circum-Antarctic ACC pelagic system (Rau et al. 1991, 1992). This may be different in carbon isotope signatures of benthic macroalgae (Fischer and Wiencke 1992), which may be 
Fig. 3 Conceptual model of the SPOM driven part of the Bouvet Island food web (macroalgae and grazers are not shown) based on all information available from sites within the ACC. The SPOM box includes all living nano- and micro-plankton as well as dead organic matter. Arrows leading back to the group/species itself represent cannibalism Bouvet Island and comparable

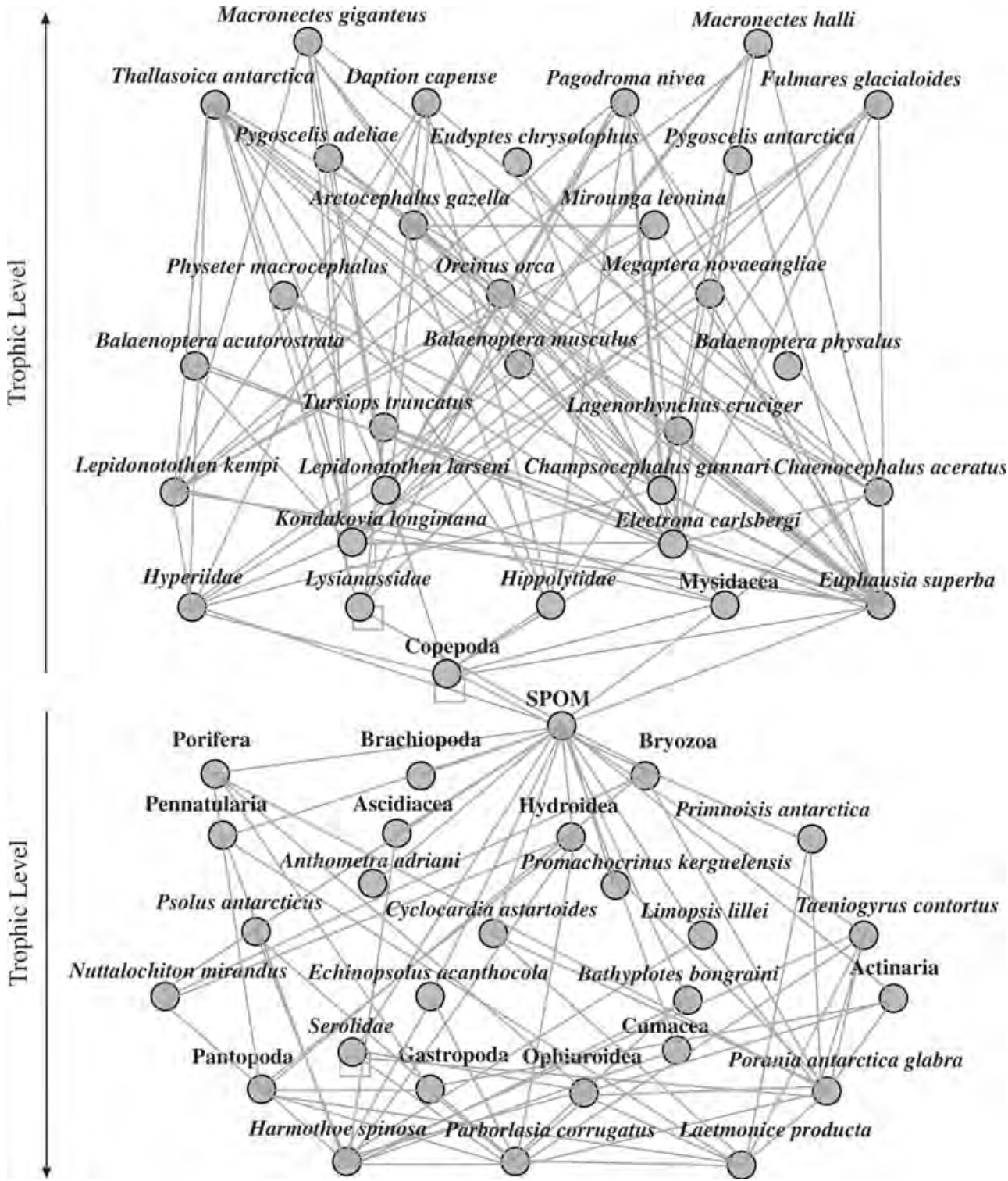

affected by local conditions such as light regime. Nevertheless, there is some evidence that such site-specific differences are smaller than the general differences between microalgae and macroalgae (Kaehler et al. 2000, 2005). With respect to substrate and hydrographic regime, the shallow water benthic environment (above $100 \mathrm{~m}$ ) is likely to be quite similar around Bouvet Island, Anvers Island, South Sandwich Islands or the Prince Edward Islands (see e.g. Perissinotto et al. 1992). Therefore, we expect similar communities, mainly composed of macroalgae and their grazers (see e.g. Dunton 2001; Iken et al. 1997; Kaehler et al. 2000; Corbisier et al. 2004), and a suspension feeder-predator assemblage as encountered below $100 \mathrm{~m}$. We know neither the extent nor the exact taxonomic composition of this macroalgae - grazer subsystem at Bouvet Island, albeit there is some anecdotal evidence of its existence: rocky surfaces in the swell zone appeared to be colonized by algae, and algal debris appeared to be present on some pebble beaches, as indicated by visual inspection from ship and helicopter.

Owing to the structural similarity of the system to other Sub-Antarctic and Antarctic open ocean systems (e.g. Hopkins 1993) and the conservative feeding behaviour of species, we assume the proposed food web to be representative for Bouvet Island. Given that both the isotope data and the feeding link data cover the major trophic groups from the pelagic and the benthic compartment, we are confident that our first attempt at the trophic structure of Bouvet Island is founded on a sound base.

\section{Primary food sources}

Unlike the shelf ice limited high Antarctic seas, which rely on pelagic primary production and ice algae production (Rau et al. 1991, 1992), many near shore Sub- 
Antarctic ecosystems are heavily subsidized by carbon from benthic primary producers, i.e. microalgae and particularly macroalgae (Attwood et al. 1991; Fischer and Wiencke 1992; Dunton 2001; Kaehler et al. 2005).

Shallow-water primary producers are consumed by a variety of species covering a wide trophic range from exclusive herbivores, e.g. the gastropod Laevilittorina antarctica, to high level omnivores such as the fish species Notothenia coriiceps/neglecta (Barrera-Oro and Casaux 1990; Iken et al. 1997; Kaehler et al. 2000, 2005; Dunton 2001).

None of these known macroalgal consumers were found in our samples, indicating that they are restricted to the depth zone of macroalgal presence. Compared to SPOM as well as to potential consumer species, macroalgal isotopic signatures are particularly high in $\delta^{15} \mathrm{~N}$ $(0.6-9.4 \%)$ and stretch across an extremely wide range in $\delta^{13} \mathrm{C}(<-35$ to -11.5 , Fig. 2b). Hence stable isotopes can provide no evidence that macroalgal matter enters the deeper part of the benthic food web analysed here in significant proportions, either directly or via the SPOM pool. However, it remains to be seen whether future sampling will indicate a relative importance of macroalgae or an absence of macroalgal consumers at Bouvet, if macroalgae are scarce. We do not have enough information on macroalgal abundance and distribution to exclude the possibility that some of the primary producers might be important, even though this seems unlikely at present.

Degradation and assimilation of macroalgal matter through detrital food webs is a common feature in many nearshore systems of temperate (Adin and Riera 2003) as well as Antarctic regions (Dunton and Schell 1987; Iken et al. 1997; Corbisier et al. 2004; Kaehler et al. 2005). Precondition for this pathway, however, are comparatively calm hydrographic conditions, which allow sedimentation of SPOM, formation of soft bottoms and development of the corresponding deposit feeding community. Such conditions exist in well-protected bays and coves such as Admiralty Bay and Potter Cove at King George Island or Palmer Station Bay at Anvers Island (Iken et al. 1997; Dunton 2001; Corbisier 2004), but not at Bouvet Island (e.g. average current speed $>30 \mathrm{~cm} / \mathrm{s}$, Hofmann 1985) and similarly exposed shores. Here, macroalgal production that is not consumed directly by herbivores is likely to be exported eastwards to the open ocean by the ACC. Therefore we assume pelagic primary production to be the principal food source of the Bouvet marine ecosystem. The ACC is a highly productive frontal area by itself, but Perissinotto et al. (1992) showed that over the Bouvet Island shelf plankton standing stock and production are even higher, most likely owing to the island mass effect which causes local upwelling (IME, Doty and Oguri 1956; Heywood et al. 1990).

\section{Trophic structure}

When macroalgae and grazers are excluded and all living nano- and micro-plankton as well as dead organic matter are summarized into one SPOM box, then this SPOM fuelled marine food web is clearly separated in a pelagic and a benthic part (Fig. 3). The benthic system is dominated by (1) a variety of suspension feeders which are all linked directly to SPOM and (2) mobile benthic predators. Competition between many suspension-feeding taxa may be reduced significantly by consumption of different size fractions and/or types of SPOM (Orejas et al. 2001). Among the predators, nemerteans, asteroids and polychaetes are quite flexible in their alimentation, as indicated by their wide range in stable isotope signatures (Fig. 2c) as well as by the many documented feeding links. This has also been observed on the eastern Weddell Sea shelf where most of the structuring compartments were regarded as omnivores (Jarre-Teichmann et al. 1997). Apparently, there exist only a few direct links between pelagic animals and benthic predators. Our data include the ophiuroid Ophiurolepis spp. (feeding on euphausiids, Dahm 1996). Other Antarctic benthic predators of pelagic animals not found here but known to be present in the ACC region are for example the hydrozoan Tubularia ralphii (copepods, Orejas et al. 2001) and the anthozoan Anthomastus bathyproctus (salps, Orejas et al. 2001).

The alimentation of the pelagic top predators (pelagic fish, squid, whales and land-based predators) appears to be much less variable than the one of the benthic predators. Pelagic predator isotope variability is lower (Fig. 2d) with diets consisting mainly of krill, hyperiid amphipods, mysids and decapods (Fig. 3; Dewitt et al. 1990; Mc Kenna 1991; Bushula et al. 2005).

\section{Conclusions}

At present, our Bouvet trophic model shows some obvious gaps, mainly with respect to the macroalgaegrazer complex as well as regarding the role of demersal fish species, which were absent in our samples but apparently play an important role in Antarctic shelf areas (Barrera-Oro and Casaux 1990; Gröhsler 1994; Brenner et al. 2001; Mintenbeck 2001).

Nevertheless, a rather clear picture emerges that shows Bouvet Island as a benthic "oasis" within a selfsustaining open ocean pelagic system. Except for the hitherto unknown macroalgae-grazer complex, the whole benthic food web is coupled directly to SPOM, and the detritus food web, which is typical for most benthic systems (Jarre-Teichmann et al. 1997), is missing completely.

Acknowledgements We are indebted to a large number of colleagues who contributed to the wealth of information on the ecology of Bouvet Island and similar Antarctic sites. We thank Prof. Greg Rau (Atmospheric Science Division, Livermore, USA) for the generous data contribution to our data set. We are grateful to Prof. Andrew Clarke (British Antarctic Survey, Cambridge) and two anonymous referees for their constructive comments on an earlier version of this manuscript. 


\section{References}

Adin R, Riera P (2003) Preferential food source utilization among stranded macroalgae by Talitrus saltador (Amphipoda, Talitridae): a stable isotopes study in the northern coast of Brittany (France). Est Coast Shelf Sci 56:91-98

Arntz WE, Brey T (2005) The Expedition ANTARKTIS XXI/2 (BENDEX) of RV "Polarstern" in 2003/2004. Ber Polarforsch 503

Arntz WE, Thatje S (2005) Biogeographic and phylogenetic relationships between sub- and high Antarctic fauna: sampling at Bouvet Island. In: Arntz WE, Brey T (eds) The Expedition ANTARKTIS XXI/2 (BENDEX) of RV "Polarstern" in 2003/ 2004. Ber Polarforsch 503:108-111

Arntz WE, Brey T (2003) The expedition ANTARKTIS XIX/ 5 (LAMPOS) of RV "Polarstern" in 2002. Ber Polarforsch 462

Attwood CG, Lucas MI, Probyn TA, McQuaid CD, Fielding PJ (1991) Production and standing stocks of the kelp Macrocystis laevis Hay at the Prince Edward Islands, Subantarctic. Polar Biol 11:129-133

Barrera-Oro ER, Casaux RJ (1990) Feeding selectivity in Notothenia neglecta Nybelin, from Potter Cove, South Shetland Islands, Antarctica. Antarct Sci 2:207-213

Bergstrom DM, Chown SL (1999) Life at the front: history, ecology and change on Southern Ocean islands. Trends Evol Ecol $14: 472-477$

Brenner M, Buck BH, Cordes S, Dietrich L, Jacob U, Mintenbeck K, Schröder A, Brey T, Knust R, Arntz WE (2001) The role of iceberg scours in niche separation within the Antarctic fish genus Trematomus. Polar Biol 24:502-507

Bushula T, Pakhomov EA, Kaehler S, Davis S, Kalin RM (2005) Diet and daily ration of two nototheniid fish on the shelf of the sub-Antarctic Prince Edward Islands. Polar Biol (in press)

Chown SL, Gaston KJ (2002) Island-hopping invaders hitch a ride with tourists in South Georgia. Nature 408:637

Cloern JE, Canuel EA, Harris D (2002) Stable carbon and nitrogen isotope composition of aquatic and terrestrial plants of the San Francisco Bay estuarine system. Limnol Oceanogr 47:713-729

Connor EF, Simberloff D (1978) Species number and compositional similarity of the Galapagos flora and avifauna. Ecol Monogr 48:219-248

Cooper J, Enticott JW, Hecht T, Klages N (1984) Prey from three chinstrap penguins Pygoscelis antarctica at Bouvet Island, December 1982. S Afr Nav Antarkt Deel 14:32-33

Corbisier TN, Petti MAV, Skowronski RSP, Brito TAS (2004) Trophic relationships in the nearshore zone of Martel Inlet (King George Island, Antarctica): $\delta^{13} \mathrm{C}$ stable isotope analysis. Polar Biol 27:75-82

Croxall JP (1984) Seabird ecology In: Laws RM (ed) Antarctic ecology. London Academic, London, pp 533-616

Dahm C (1996) Ecology and population dynamics of Antarctic ophiuroids (Echinodermata). Ber Polarforsch 194:1-289

Dewitt HH, Heemstra PC, Gon O (1990) Nototheniidae In: Gon O, Heemstra PC (eds) Fishes of the southern ocean. J.L.B. Smith Institute of Ichthyology, Grahamstown, pp 279-331

Doty MS, Oguri M (1956) The island mass effect. J Cons Perm Int Explor Mer 22:33-37

Dunton KH (2001) $\delta^{15} \mathrm{~N}$ and $\delta^{13} \mathrm{C}$ measurements of Antarctic Peninsula fauna: trophic relationships and assimilation of benthic seaweeds. Am Zool 41:99-112

Dunton KH, Schell DM (1987) Dependence of consumers on macroalgal (Laminaria solidungula) carbon in an Arctic kelp community: $\delta^{13} \mathrm{C}$ evidence. Mar Biol 93:615-625

Fischer G, Wiencke C (1992) Stable carbon isotope composition, depth distribution and fate of macroalgae from the Antarctic Peninsula region. Polar Biol 12:341-348

Foldvik A, Gammelsrød T, Tørresen T (1981) Measurements of ocean current and bottom pressure near Bouvetøya, JanuaryMarch 1979. Skrifter Norsk Polarinstitut 175:105-112
Frenot Y, Chown SL, Whinam J, Selkirk PM, Convey P, Skotnicki M, Bergstrom DM (2005) Biological invasions in the Antarctic: extent, impacts and implications. Biol Rev 80:45-72

Fry B (1988) Food web structure on Georges Bank from stable C, $\mathrm{N}$, and $\mathrm{S}$ isotopic compositions. Limnol Oceanogr 33:11821190

Gannes LZ, O'Brien DM, DelRio MC (1997) Stable isotopes in animal ecology: assumptions, caveats, and a call for more laboratory experiments. Ecology 78:1271-1276

Gaston KJ, Jones AG, Hänel C, Chown SL (2003) Rates of species introduction to a remote oceanic island. Proc R Soc Lond B 270:1091-1098

Gaston KJ (1996) Species richness: measure and measurement. In: KJ Gaston (ed) Biodiversity: a biology of numbers and difference. Blackwell, Oxford, pp 77-113

Gröhsler T (1994) Feeding habits as indicators of ecological niches: Investigations of Antarctic fish conducted near Elephant Island in late autumn/winter. 1986. Arch Fish Mar Res 42 (1):17-34

Haftorn S (1986) A quantitative analysis of the behaviour of the Chinstrap penguin Pygoscelis antarctica and Macaroni penguin Eudyptes chrysolophus on Bouvetøya during the late incubation and early nestling periods Polar Res 4:33-45

Hall SJ, Raffaelli D (1991) Food-web patterns: lessons from a species - rich web. J Anim Ecol 60:823-842

Heywood KJ, Barton ED, Simpson JH (1990) The effects of flow disturbance by an oceanic island. J mar Res 48:55-73

Hofmann EE (1985) The large-scale horizontal structure of the Antarctic circumpolar current from FGGE drifters. J Geophys Res 90:7087-7097

Hopkins TL, Lancraft TM, Torres JJ, Donnelly J, (1993) Community structure and trophic ecology of zooplankton in the Scotia Sea marginal ice zone in winter (1988). Deep Sea Res I 40:81-105

Iken K, Barrera-Oro ER, Quartino ML, Casaux RJ, Brey T (1997) Grazing by the Antarctic fish Notothenia coriiceps: evidence for selective feeding on macroalgae. Antarct Sci 9(4):386-391

Isaksen K, Huyser O, Kirkman S, Wanless R, Wilson W (2000) Studies of seabirds and seals on Bouvetøya 1989/1999. Norsk Polarinstitutt Internrapport 2. Tromsø: Norsk Polarinstitutt

Jacob U, Mintenbeck K, Brey T, Knust R, Beyer K (2005) Stable isotope food web studies: a case for standardized sample treatment. Mar Ecol Prog Ser 287:251-253

Jacob U, Mintenbeck K, Brey T (2003) Trophic position of abundant invertebrate species along the Scotia Arc and the Antarctic Peninsula. In: Arntz WE, Brey T (eds) The Expedition ANTARKTIS XIX/5 (LAMPOS) of RV "Polarstern" in 2002. Ber Polarforsch 462:60-61

Jarre-Teichmann A, Brey T, Bathmann UV, Dahm C, Dieckmann GS, Gorny M, Klages M, Pages F, Plötz J, Schnack-Schiel SB, Stiller M, Arntz WE, (1997) Trophic flows in the benthic shelf community of the eastern Weddell Sea, Antarctica. In: Battaglia B, Valencia J, Walton DWH (eds) Antarctic communities: species, structure and survival. Cambridge University Press, Cambridge, pp 118-134

Kaehler S, Pakhomov EA, Kalin, RM, Davis S (2005) Trophic importance of kelp-derived suspended particulate matter in a through-flow sub-Antarctic system. Mar Ecol Prog Ser (in press)

Kaehler S, Pakhomov EA, McQuaid CD (2000) Trophic structure of the marine food web at the Prince Edward Islands (Southern Ocean) determined by $\delta^{15} \mathrm{~N}$ and $\delta^{13} \mathrm{C}$ analysis. Mar Ecol Prog Ser 208:13-20

Keith DG, Harck BIB, Ryan PG, Mehlum F (2002) Post-breeding dispersal of Northern Giant Petrels Macronectes halli from Marion to Bouvet Island. Mar Ornithol 30:31

Kirkman SP, Hofmeyr GJG, Bester MN, Isaksen K (2001) Counts of southern elephant seals, Mirounga leonina, at Bouvet Island. Polar Biol 24:62-65

Lesage V, Hammill MO, Kovacs KM (2001) Marine mammals and the community structure of the Estuary and Gulf of St Lawrence, Canada: evidence from stable isotope analysis. Mar Ecol Prog Ser 210:203-221 
Mariotti A (1984) Atmospheric nitrogen is a reliable standard for natural ${ }^{15} \mathrm{~N}$ abundance measurements. Nature 303:685-687

Martinez ND (1991) Artifacts or attributes? Effects of resolution on the Little Rock Lake food web. Ecol Monogr 61:367-392

Mc Kenna JE Jr (1991) Trophic relationships within the Antarctic demersal fish community of South Georgia Island. Fish Bull 89:643-654

Mintenbeck K (2001) The food web of the demersal fish fauna in undisturbed and disturbed areas on the eastern Weddell Sea shelf. Diploma Thesis, University of Bremen, $130 \mathrm{p}$

Orejas C, Gilli JM, Lopez-Gonzalez PJ, Arntz WE (2001) Feeding strategies and diet composition of four Antarctic cnidarian species. Polar Biol 24:620-627

Pakhomov EA, Froneman PW (1999) The Prince Edward Island pelagic ecosystem, south Indian Ocean: a review of achievements, 1976-1990. J Mar Syst 18:355-367

Perissinotto R, Laubscher RK, McQuaid CD (1992) Marine productivity enhancement around Bouvet and the South Sandwich Islands (Southern Ocean). Mar Ecol Prog Ser 88:41-53

Perissinotto R, McQuaid CD (1992) Land-based predator impact on vertically migrating zooplankton and micronecton advected to a southern archipelago. Mar Ecol Prog Ser 80:15-27

Perissinotto R, Allanson BR, Boden BP (1990) Trophic relations within the island seas of the Prince Edward Archipelago, Southern Ocean. In: Barnes M, Gibson RN (eds) Trophic relationships in the marine environment. Aberdeen University Press, Aberdeen, pp 296-314
Rau GH, Hopkins TL, Torres JJ $(1991){ }^{15} \mathrm{~N}:{ }^{14} \mathrm{~N}$ and ${ }^{13} \mathrm{C}:{ }^{12} \mathrm{C}$ in Weddell Sea invertebrates: implications for feeding diversity. Mar Ecol Prog Ser 77:1-6

Rau GH, Ainley DG, Bengston JL, Torres JJ, Hopkins TL (1992) ${ }^{15} \mathrm{~N}:{ }^{14} \mathrm{~N}$ and ${ }^{13} \mathrm{C}:{ }^{12} \mathrm{C}$ in Weddell Sea birds, seals and fish: implications for diet and trophic structure. Mar Ecol Prog Ser 84:1-8

Schmidt K, Atkinson A, Stübing D, McClelland JW, Montoya JP, Voss M (2003) Trophic relationships among Southern Ocean copepods and krill: some uses and limitations of a stable isotope approach. Limnol Oceanogr 48:277-289

Vander Zanden MJ, Shuter B, Lester NP, Rasmussen JB (2000) Within and among population variation in the trophic position of a pelagic predator, lake trout (Salvelinus namaycush). Can J Fish Aquat Sci 57:725-731

Wada E, Terazaki M, Kabaya Y, Nemoto T (1987) ${ }^{14} \mathrm{~N}$ and ${ }^{13} \mathrm{C}$ abundances in the Antarctic Ocean with emphasis on the biogeochemical structure of the food web. Deep-Sea Res $34(5 /$ 6):829-841

Walker I (1985) The structure and ecology of the microfauna in the central Amazonian forest stream "Igarape de Cachoeira". Hydrobiologia 122:137-152

Warren PH (1989) Spatial and temporal variation in the structure of a freshwater food web. Oikos 55:299-311 